\title{
CORRESPONDENCE
}

\author{
Liquor licensing and public health \\ J S Horner, MFCM; M M Glatt, FRCPSYCH; \\ B $\mathrm{H}$ Wilkins................ 768 \\ Beta-blockers in anxiety and stress \\ K G F Benton, MB. . . . . . . . . . . . . . . . .769 \\ Diagnosis of intracranial haemorrhage \\ C A Gleadhill, FRCSED . . . . . . . . . . . . . 769 \\ Pseudo-obstruction due to clonidine \\ G E Bauer, FRCP, and K J Hellestrand . . . . . 769 \\ Propranolol schedule before paradoxical \\ hypertension \\ N J Yorkston, FRACP, and others.........769 \\ Toxic effects of propranolol on the heart \\ G Frithz, MD................. 769 \\ IUD and congenital malformation \\ B Alderman, MRCOG; R Snowden, PHD . . . . 770 \\ Immunisation against whooping cough \\ $\mathrm{N}$ W Preston, FRCPATH............. 770
}

A place to be born

Margaret Stacey, BSC; D van Alten, $M D$, and others..................

Dangerous labelling

D W Bracey, FRCS ............... 771

Dispersal of biliary calculi by irrigation

S J A Powis, frCS.................772

SI units and blood pressure

F Gross, MD ................. 772

An eye-pad hazard

$\mathrm{R}$ Wall, $\mathrm{MB} \ldots \ldots \ldots \ldots \ldots \ldots \ldots \ldots \ldots \ldots$

Whither scabies?

F F Hellier, FRCP . . . . . . . . . . . . . 772

GMC election

Lord Platt, FRCP..............772

Treatment of myeloma kidney

T J Hamblin, MRCPATH. . . . . . . . . . 772
How much can ancillaries take over ?

D J D Stevenson, MD . . . . . . . . . . . 772

Medical manpower

W J Appleyard, MRCP . . . . . . . . . . . . .773

Hospital practitioner grade

A D Mackenzie, FRCSED, and I A Khan, FRCS . . 773

Incremental payments for consultants

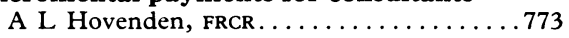

Points from letters Starch peritonitis (P F Plumley); Attempted suicide in labour (H I Lockett); Promise and performance (L C de R Epps); Long-term postinfarction treatment with practolol (D M D Lambert); Rib pain ( $R T$ D Fitzgerald; J B Tracey); Hospital practitioner grade (Catherine Woodyard); Febrile fits and diazepam (H G Smyth); Treatment of frozen shoulder (A W Fowler); Supervision of repeat prescribing ( $\mathrm{R}$ D Walker)............774
Correspondents are urged to write briefly so that readers may be offered as wide a selection of letters as possible. So many are being received that the omission of some is inevitable. Letters should be signed personally by all their authors.

\section{Liquor licensing and public health}

SIR,-I am sure that your readers will disregard Dr C W Clayson's (13 March, p 649) extraordinary attack on the objectivity of your timely leading article (14 February, p 359) concerning the unhelpful legislation now before Parliament. He offers no evidence in support of his apparent contention that existing licensing measures are aggravating the problems associated with the current increase in alcohol consumption. Indeed, his own committee and that of Lord Erroll were able to provide no convincing arguments why the views of the expert witnesses they received should be so firmly set aside. Opposition to their proposals comes not from an eccentric minority but from those most closely concerned with the increasing alcohol problem in this country. Sir Bernard Braine, chairman of the National Council on Alcoholism, deserves more support in Parliament than he has so far received. Professional workers will welcome the more objective and scientific approach of Sir George Godber (13 March, p 638).

When society last faced major social problems as a result of excessive alcohol consumption in this country it introduced restrictive legislation. Historically these efforts succeeded in their objective. Ever since these laws began to be liberalised in the early 1960s we have seen a dramatic and progressive increase in alcohol consumption which $\mathrm{Dr}$ Clayson himself documents in his letter. Scandinavian experience is similar. Yet faced with the social problems of today our society proposes, without a shred of objective evidence, to take an exactly opposite approach to methods which have proved to be effective previously. $\mathrm{Sir}$, your description of these proposals as "a gamble with the nation's health" is a singularly appropriate one.

\section{J STUART HORNER}

East Croydon, Surrey

SIR,-The private member's Bill to enable public houses to remain open longer and to provide accommodation for children (14 February, p 359) was given an unopposed second reading in the Commons on 27 February. In the debate the existing licensing laws were described as "archaic." For many centuries alcohol misuse and inebriety had been rampant in Britain ${ }^{1}$; however, by the middle of the 20th century there had been such improvement in this field that (rather over-optimistically) the Ministry of Health and leading medical journals considered the problem of alcoholism in this country to be a thing of the past. ${ }^{1}$ How had. this welcome change come about? Obviously many inter acting factors must have been involved (social changes and improvements, emergence of competitive recreations, etc). Yet chronologically the improvement followed shortly after the introduction of severe restrictive legislation during the 1914-18 war which the Government wisely preferred to the alternative of total prohibition adopted in other countries. While further research is needed, many observers attributed the remarkable improvement at least partly to "the administrative restriction on hours of sale, dilution of beers and spirits, and direct restrictions on the supply of liquor." 2 In spite of minor alterations the licensing restrictions of the 1914-18 war were retained in subsequent years. Such "archaic" licensing laws may thus have contributed greatly to reducing a problem that had plagued this country for many centuries. ${ }^{1}$

Is the present the best time to relax the licensing laws? All evidence points to the steady increase of alcohol consumption misuse in Britain over the past two decades in particular among the young. ${ }^{3}$ De Lint $^{4}$ has reported that careful studies carried out by the Ontario Addiction Research Foundation have clearly indicated a close link between "overall levels of alcohol consumption and the prevalence of chronic excessive use"; and he concludes that "there is now ample documentation to show that the gradual relaxation of control measures and particularly of price controls has done much to promote the proliferation of alcohol use patterns in many parts of the world and consequently to bring about a rapid rise in excessive consumption and related health damage."

Those in favour of relaxing the licensing laws in spite of the possible risks for the "few"-the alcoholics-usually claim that they constitute a great inconvenience for the great majoritythe "social drinkers." "alcoholism" but also its earlier phases and predecessor "alcohol misuse," are medical as well as social problems and should be of interest to doctors, who are concerned with prevention and obviously not only, or mainly, with treating established illness. Today's heavily drinking youngster may often be the "alcoholic" of tomorrow. In the past the medical profession on the whole has remained indifferent to the "drink problem"-with rare exceptions, such as a Memorandum of the Royal College of Physicians 250 years ago at the time of the gin epidemic and of a BMA committee (in association with the Magistrates Association) deploring the lack of treatment facilities 15 years ago. The Bill, which quite possibly may increase the availability and consumption of alcohol, constitutes-as you rightly say-a 